Cuadernos de Filología Clásica. Estudios Latinos

ISSN: 1131-9062

http://dx.doi.org/10.5209/CFCL.57804

\title{
Horacio y su historia de la sátira
}

\author{
Rosario Cortés Tovar ${ }^{1}$
}

Recibido: 29 de junio de 2017 / Aceptado: 13 de septiembre de 2017

Resumen. La historia de la sátira trazada por Horacio en sus Sermones empieza con Lucilio, el inuentor del género, que se inspira en el espíritu satírico de la vieja comedia ática, pero no desarrolla todas sus potencialidades. A este primer tiempo brillante, pero fallido por haberse estancado la sátira en manos de los seguidores de Lucilio que imitaron solo sus defectos, le sigue un segundo tiempo en el que, tras los intentos frustrados del neotérico «Varrón Atacino y otros» por reencauzar el género, Horacio consigue llevarlo a la perfección que le permite entrar en el canon clásico. De esta forma, Horacio no es el primus en sentido cronológico pero sí en el sentido de excelencia y desde ahí construye la tradición de la sátira de acuerdo con sus propios intereses, pero hay que aceptar que la extraviada evolución postluciliana de la sátira jugó a su favor.

Palabras clave: Horacio, género sátira, historia literaria inmanente.

\section{[en] Horace and His History of Satire}

Abstract. The history of satire as traced by Horace in his Sermons begins with Lucilius, the inuentor of the genre, who takes his inspiration from satirical spirit of Old Attic Comedy, but does not develop it in all its potential forms. This brilliant first stage was also flawed, as satire had become stuck in the hands of Lucilius' followers, who limited themselves to imitating his defects. It was followed by a second stage in which, after the frustrated attempts of the neoteric «Varro Attacinus and others» to redirect the genre, Horace managed to take it to a level of perfection that allowed it to enter the classical canon. Thus, although Horace was not the primus in the chronological sense, he was indeed the first to bring the genre to excellence and from there build the tradition of satire in line with his own interests. Nonetheless, it must be accepted that its misdirected post-Lucilius evolution played in his favour.

Keywords: Horace, genre of satire, immanent literary history.

Cómo citar: Cortés Tovar, R., «Horacio y su historia de la sátira», Cuad. Filol. Clás. Estud. Lat. 37.2 (2017), 239-263.

El título de este trabajo subraya el carácter subjetivo de la historia que Horacio nos ofrece de la sátira en sus piezas programáticas o literarias ${ }^{2}$. La construcción por los poetas de la tradición en la que ellos inscriben sus obras es una operación propia de la historia literaria inmanente y ha sido objeto de algunos estudios en las dos últimas

\footnotetext{
$1 \quad$ Universidad de Salamanca rocor@usal.es.

2 Este es el adjetivo que prefiere Brink $(1963,153-177)$ ya que las estudia como el primer estadio de sus textos críticos-literarios. Mañas Núñez (2006, 25-31) también se ocupa de ellas juntamente con el Ars Poetica.
} 
décadas ${ }^{3}$. Esta forma de abordar desde dentro la historia literaria está lejos de ser objetiva, pues quien la lleva a cabo defiende sus intereses ya que él mismo forma parte de esa historia y puede utilizarla para crear su propia imagen dentro de ella; así que inevitablemente el resultado de su construcción despierta dudas sobre la posible manipulación de los hechos. Horacio no escapa a estas sospechas y la mayoría de los críticos no lo consideran buen historiador de la literatura latina, bien porque no contempla la literatura del pasado en relación con el tiempo y lugar en el que fue compuesta, sino que la interpreta y evalúa desde la perspectiva de su propio tiempo (Feeney 2002, 179) ${ }^{4}$, bien porque sus juicios histórico-literarios aparecen en contextos de polémica literaria, que los contaminan con distorsiones interesadas (Tarrant $2007,64)^{5}$.

Vamos a estudiar cómo Horacio construye la historia de la sátira en sus sátiras literarias: $1.4 ; 1.10$ y 2.1 . No se trata tanto de analizarlas con el propósito de estudiar su programa satírico ${ }^{6}$ como de ver cómo traza en estos poemas la tradición previa del género de manera que encaje en ella su 'nueva sátira', la que él adapta a las exigencias estéticas y políticas de su tiempo. Como dice Cucchiarelli (2001, 172-174), cuando un poeta busca una nueva vía para un género, lo mejor es volverse a indagar sobre los orígenes y la tradición del mismo y reconstruirla de acuerdo con el proyecto propio. Eso es precisamente lo que hace Horacio, poeta y crítico al mismo tiempo .

Abordaremos su acción en el contexto más amplio de la historia literaria inmanente en el que encontramos construcciones de otras tradiciones genéricas.

Citroni (2001), en su estudio «Affermazioni di priorità e coscienza di progresso artistico nei poeti latini», señala que desde Ennio cada uno de los poetas latinos se declara primus en el género que cultiva. En efecto, en el proemio del libro 7 de $\mathrm{An}$ nales Ennio afirma que antes de él nadie había escalado Musarum scopulos ni había entendido la poesía como una operación de trabajo cuidadoso con la palabra (dicti studiosus): él fue el primero que se «atrevió a abrir ese camino» (nos ausi reserare) (7.1.215-217 V).

Después encontramos la afirmación de prioridad en otros poetas: en Virgilio Ecl.6.1-2 y Georg.3.10-11 y, por supuesto, en Horacio, que se proclama primus en la lírica eólica y el yambo arquiloqueo, porque, según él, fue el primero en introducir sus ritmos en el Lacio (Carm.3.30.12-14 y Epist.1.19.21-23) ${ }^{8}$. Ambos géneros habían sido cultivados antes por Catulo y Levio, pero Horacio silencia a estos poetas

Así Hinds (1997), que subraya el carácter subjetivo de este tipo de construcción frente a las narraciones de las Historias de la literatura tradicionales que se presentan como objetivas, y también los trabajos de Barchiesi (2001) Citroni (2001) y Cortés Tovar (2017). Sobre «Historia literaria immanente» y las cuestiones que abarca v. Schmidt (2001, IX-XVIII).

4 Tenemos que aclarar que Feeney saca esta conclusión de su análisis de la Epístola a Augusto, de manera que pasa por alto que Horacio al menos cuando critica a Lucilio en Sat.1.10.65-71 adopta una perspectiva histórica, como veremos luego.

5 Goldberg $(2005,156-174)$ confronta las críticas que Horacio le dedica a Lucilio con fragmentos de su obra y pone de relieve la visión sesgada que tales críticas dan de ella.

$6 \quad$ Ya analizamos estas tres sátiras en nuestros trabajos de 1994 y 2006.

7 Comparte esta idea Hooley $(2007,28)$, que llega a decir que Horacio inventó la sátira al dotarla de un inuentor, pues sin él Lucilio solo habría representado una corriente romana de la invectiva. Sobre la invención del género sátira v. también Muecke $(2013,284)$.

8 Sobre reclamaciones de primacía e innovación poética en la Historia literaria romana en el periodo augústeo merece la pena leer además Hinds (1998, 52-63). 
relegándolos a una fase de experimentación que le permite presentarse él mismo como el responsable de la consolidación de ambos géneros en la literatura latina ${ }^{9}$.

En estas declaraciones de prioridad primus no tiene solo el sentido cronológico de que el poeta está dando los primeros pasos en el género o es simplemente el iniciador del mismo en Roma, sino que primus tiene también el significado de excelencia: primus es el poeta que ha llevado al género en latín a la perfección que había alcanzado en su modelo griego. El principio aristotélico de evolución de las artes desde sus inicios rudimentarios a la perfección, que aparece de forma clara como guía en el Brutus de Cicerón ${ }^{10}$, queda anulado en las declaraciones de Horacio que acabamos de ver y en las de otros poetas.

También en esta operación de silenciar a los predecesores fue Ennio el modelo, pues no incluyó en la tradición de la poesía épica los poemas épicos anteriores: la traducción al latín de la Odisea, de Livio Andrónico, y el Bellum Poenicum de Nevio (Ann.7.1.213-214V). Ennio se presenta a sí mismo como el Homero latino, que desprecia el viejo verso saturnio, adopta como inspiradoras de su poesía a las Musas, e innova formalmente adaptando al latín el hexámetro dactílico de la épica griega. Desde esta brillante posición deja a un lado el pasado latino del género, no establece continuidad con él: se lo salta para ponerse a la altura de Homero; es al mismo tiempo el primus, 'primer' poeta épico y el poeta que lleva a la perfección homérica la épica en latín.

Esta maniobra recibe una dura crítica de Cicerón, que lo acusa de mentir en los versos de Annales a los que acabamos de referirnos y de ocultar entre los versos primitivos de los vates y los faunos la obra de $\mathrm{Nevio}^{11}$, que finge despreciar. Cicerón en Brut.76 lo desenmascara y termina reprochándole que no admita lo que le debe a su predecesor, pues (tú) a Naevio uel sumpsisti multa, si fateris, uel, si negas, surripuisti: «si lo confiesas, tomaste muchas cosas de Nevio, si lo niegas, se las robaste».

Así que Cicerón ya denunció la manipulación de la historia literaria construida por Ennio para subrayar la primacía de su propia obra.

La historia de la sátira es más compleja que la de los géneros anteriormente mencionados y también lo es la construcción horaciana de la misma. Varios factores contribuyen a su complejidad: el hecho de que, frente a otros géneros, carezca de un único modelo griego evidente; las dos fases de su desarrollo que encontramos recogidas por el gramático del siglo IV Diomedes ${ }^{12}$; la existencia en Roma de dos genera

9 Citroni (2001, 294-301). Tarrant $(2007,70)$ también afirma que las anticipaciones de Catulo en lírica y yambo no invalidan la reclamación de prioridad de Horacio, puesto que su predecesor no había escrito un corpus sustancial de poesía de tales géneros. Cucchiarelli $(2001,48)$, por su parte, le atribuye el silencio sobre los predecesores romanos a la perspectiva clasicista de los poetas romanos augústeos, concentrados en buscar y seguir a los modelos griegos "clásicos".

10 El principio de la evolución de las artes desde sus primeros tanteos a la consecución de la perfección domina la historia de la oratoria romana de Cicerón, que recorre la evolución de este género hasta que alcanza el 'telos' de perfección en su propia obra. En Brut.71 afirma Cicerón: nihil est enim simul et inuentum et perfectum, nec dubitari debet quin fuerint ante Homerum poetae, quod ex eis carminibus intellegi potest quae apud illum et in Phaeacum et in procorum epulis canuntur.

11 Scripsere alii rem/ uorsubus, quos olim Fauni uatesque canebant (ENN.Ann.7.1.213-214V)

12 Gramm.1,485.30. Keil: Satura dicitur tamen apud Romanos nunc quidem maledicum et ad carpenda hominum uitia archaeae comoediae charactere compositum, quale scripserunt Lucilius et Horatius et Persius. sed olim carmen quod ex uariis poematibus constabat satura uocabatur, quale scripserunt Pacuuius et Ennius. Freudenburg $(2005,5)$ menciona también el testimonio de Porfirión sobre las dos fases de la sátira, pero la verdad es que en el texto de Porfirión no encontramos nada semejante. 
de sátira, la hexamétrica o formal y la menipea, prosimétrica; la reivindicación de romanitas total para el género expresada por Quintiliano en Inst.10.1.9 que entra en aparente contradicción con la genealogía griega del mismo reclamada por Horacio en Sat.1.4.1-7, y, por último, el hecho de que Horacio no sea en este caso el primus en cultivar el género.

Para desentrañar todos estos problemas y explicarlos del modo más ordenado y claro posible, examinaremos la construcción horaciana poniéndola en relación, tanto con las motivaciones estéticas y políticas que podemos descubrir en el programa satírico de Horacio, como con otros relatos de la historia de la sátira externos a su obra.

La primera mención de Horacio de lo que puede constituir un referente genérico para el sermo se encuentra en su sátira primera ${ }^{13}$, cuando reivindica su derecho al 'spoudogéloion': quamquam ridentem dicere uerum/ quid uetat? (vv.24-25), reivindicación que reúne dos rasgos de la sátira diatríbica en la que se encuentra: humor y afirmación de una verdad moral. Pero no hay ningún género histórico en la literatura clásica antigua con este nombre: el 'spoudogéloion' sería más bien un modo, pues no se identifica con una forma determinada ${ }^{14}$, sino que aparece compartido por géneros que adoptan formas diferentes en lo que Bajtín (1984, 106-108) llamó el espacio o ámbito literario del 'spoudogéloion'. En ese espacio se confundían e identificaban diversos géneros como la diatriba, la comedia ática arcaica ${ }^{15}$ y el yambo: todos ellos tenían en común el modo de censura 'serio-cómico' y una libertad de expresión cargada con frecuencia de agresividad (Freudenburg 1993, 82-83).

Horacio hace esta reivindicación programática en su primera sátira, que forma parte de la tríada diatríbica con la que abre su obra. Estas tres sátiras se caracterizan por el tratamiento de temas propios de la ética filosófico-popular y por la estructura semi-dialogada de la diatriba ${ }^{16}$, que le permitía al diatribista entablar diálogo con un interlocutor ficticio; de ahí el título de sermo, traducción al latín de 'diatribé' ${ }^{17}$. De todas formas, Horacio ya en esta sátira marca diferencias entre su sermo y la diatriba estoico-cínica, a través de la crítica de los excesos de diatribistas estoicos doctrinarios y prolijos como Fabio (1.1.14) y Crispín (1.1.121-22; 1.3.139) ${ }^{18}$, a los

13 Sobre el carácter programático de esta sátira v. Hubbard (1981), Duffallo (2000) y Schlegel (2005)

14 Fowler (1982, 106-110) distingue entre ‘tipo' o 'género', que por su forma y contenidos bastante estables nombramos con un sustantivo (épica, tragedia etc.), y la categoría genérica 'modo', más elusiva, que nunca implica una forma externa fija y que nombramos con un adjetivo, como en este caso 'serio-cómico'.

15 Si bien el 'spoudogéloion' se ha considerado tradicionalmente un rasgo característico de la diatriba cínica, los últimos estudios sobre la presencia de la comedia vieja en las sátiras de Horacio han señalado que en la obra de Aristófanes también aparecen referencias a y definiciones del 'spoudogéloion': Cucchiarelli $(2001,41)$ señala el nexo entre 'spoudaia' y 'geloia' en Ran.389-90; Ferris-Hill (2015, 23-30) aporta Ach.497-505 como intextexto de Horacio, Sat.1.1.23-27. Por su parte Cucchiarelli $(2007,196)$ encuentra en Porfirión un nexo entre la diatriba y de la comedia vieja: Bion Aristophanis comici par dicitur fuisse (Ad epist.2.2.60)

16 Di Benedetto $(1966,56-65)$ recuerda que este modelo de comunicación se encuentra también en los Iamboi de Calímaco, de los que son deudoras las Sátiras de Horacio, especialmente de los yambos de polémica literaria.

17 La equivalencia entre ambos términos, aceptada por la mayoría de los estudiosos a partir de la tesis de Heinze (1889), le parece dudosa a Brink $(1982,300)$ debido a la incertidumbre que crean los escasos fragmentos que tenemos de la obra de Bión.

18 De lo que se deja vislumbrar en sus frags. parece que la prosa de Bión ya se distanció de los excesos de los predicadores estoico-cínicos, de modo que Horacio pudo ver en él un punto de encuentro entre el discurso filosófico-moral de la diatriba y los principios de refinamiento estilístico de la nueva poética (Cucchiarelli 2007, 196). 
que seguirá atacando en las sátiras siguientes (1-4) ${ }^{19}$. Además no tenemos en la sátira primera una afiliación explícita de su obra a la diatriba, de la que se distancia Horacio desde el primer verso: Quid fit, Maecenas,...? Horacio saca a la diatriba del espacio público de la calle y la convierte en sermo que se desarrolla en un ámbito privado y romano y más concretamente en el Círculo de Mecenas, que aparece como su interlocutor principal. A ese mundo adapta el modelo de comunicación de la diatriba, multiplicando los niveles de interlocución, de manera que junto al 'tú' del interlocutor adversario, defensor de las costumbres que el satírico critica, está el 'tú' del amigo o de los amigos con quienes comparte actitudes y valores morales ${ }^{20}$. La diatriba sería por tanto una fuente de inspiración pero no un género griego modelo en el que enmarcar la sátira ${ }^{21}$.

La primera genealogía explícita que Horacio establece para la sátira la encontramos en los primeros versos de 1.4:

Eupolis atque Cratinus Aristophanesque poetae atque alii, quorum comoedia prisca uirorum est, si quis erat dignus describi, quod malus ac fur, quod moechus foret aut sicarius aut alioqui famosus, multa cum libertate notabant. hinc omnis pendet Lucilius, hosce secutus, mutatis tantum pedibus numerisque; facetus, emunctae naris, durus componere uersus. nam fuit hoc uitiosus: in hora saepe ducentos, ut magnum, uersus dictabat stans pede in uno; cum flueret lutulentus, erat quod tollere uelles; garrulus atque piger scribendi ferre laborem, scribendi recte; nam ut multum, nil moror... ${ }^{22}$.

19 Como muy bien señala Zetzel $(1980,64)$, la 1.4 supone un cierre de la primera tríada del libro y una apertura de la siguiente: en ella se mantiene el modelo de comunicación diatríbico, pero la censura deja a un lado la homilía de moral pública y pasa a ocuparse de crítica literaria.

20 Citroni (1993, 114-125). Labate (2009², 110 [1996]) señala que Horacio en el libro primero imagina una relación triangular entre poeta, amigos y sociedad. En el libro segundo el juego de interlocutores se vuelve aún más complejo (114-116).

${ }^{21}$ Contra esta afirmación parece hablar el hecho de que Horacio se refiera aún en la Epístola a Floro a sus sátiras como Bionei sermones: Denique non omnes eadem mirantur amantque: /carmina tu gaudes, hic delectatur iambis, /ille Bioneis sermonibus et sale nigro (Epist.2.2.60-62). Nos parece, sobre todo, chocante que identifique sus sermones con el chiste caústico de las diatribas de Bión (Bion [...] mordacissimis salibus ea, quae apud poetas sunt, ita lacerauit, ut ne Homero quidem parceret, PS-ACRON. ad loc. cit.), porque en su programática 1.4.81-85 Horacio rechaza el humor del niger para su sátira. Van Rooy $(1965,65)$ cree que se trata de un añadido posterior a las afirmaciones de sus programáticas. Brink (1982, 301-302) señala que sale nigro puede tomarse como una hendíadis con Bioneis sermonibus, algo así como «la sal gorda de las sátiras al estilo de Bión» y añade que habría elegido el término sal en este contexto para proporcionar una transición adecuada a la metáfora del banquete que usa después para referirse a la variedad de gustos de tres convidados a un banquete (vv. 31-64). No acabo de encontrar satisfactorias estas explicaciones. Quizás Horacio está haciéndose eco aquí de un calificativo que usaría aquella parte de la audiencia que consideró que era demasiado ‘ácido’ en sus sátiras: Sunt quibus in satira uidear nimis acer (Sat.2.1.1).

22 Citamos por la edición de Horacio de Klingner (1959) con algunas de las correcciones ortográficas y de puntuación propuestas por Gowers (2012). 
De la comedia arcaica, un género griego clásico y prestigioso, depende enteramente Lucilio, el inuentor de la sátira en Roma. De él parte, según Horacio, la tradición de la sátira romana. No menciona a Ennio ${ }^{23}$, representante de los inicios del género, que queda así relegado con sus Saturae a una fase rudimentaria de experimentos en poesía ocasional polimétrica cercano a las misceláneas poéticas helenísticas, que no llegó a cuajar como género: la designación satura de Ennio tendría un valor descriptivo ('mezcla'), no técnico, sin pretensión de nombrar un verdadero género literario. Por eso más tarde, cuando Diomedes se refiere a la historia de la sátira solo caracteriza la fase originaria y las obras de Ennio y Pacuvio por su polimetría, lo que las diferencia de la sátira hexamétrica posterior. De todas formas, la mayoría de los críticos consideran las Saturae de Ennio un precedente de Lucilio, que llevó también a cabo experimentos mayores hasta dar con la fórmula definitiva del género ${ }^{24}$; pero no debemos olvidar que Quintiliano se refiere a la sátira polimétrica más antigua - prius saturae genus-como punto de partida de la menipea en Roma, a la que Varrón solo le habría añadido la prosa (Inst.10.1.95). Sea mayor o menor la continuidad entre la fase primitiva y las dos tradiciones satíricas posteriores, lo que parece claro es que el silencio sobre los principios de un género que no desembocan en su consolidación, es, como hemos visto, práctica habitual en las reflexiones metaliterarias de los poetas latinos ${ }^{25}$

De modo que para Horacio la historia de la sátira empieza con Lucilio al que presenta completamente dependiente de los viejos comediógrafos griegos, tanto en la censura de los que merecen la exposición pública de sus vicios (si quis erat dignus describi...multa cum libertate notabant, 3-5), como en la absoluta libertad con la que los condena. Lo único que cambió Lucilio en sus modelos fueron los 'pies y los ritmos': de la prisca tomó el espíritu satírico para cultivarlo en Roma en un género diferente ya que la sátira no es un género dramático. La comedia vieja sería un modelo potente pero parcial para la sátira luciliana, pues no la determinó formalmente.

Horacio, por su parte, traza ya en estos primeros versos una tradición literaria para la sátira al servicio de sus intereses. Lo primero que salta a la vista es que la presentación que Horacio hace de la comedia vieja contiene elementos anacrónicos: Eúpolis, Cratino y Aristófanes son presentados como censores romanos ya que sus ataques satíricos aparecen equiparados a la atribución del censor de poner la nota censoria - notabant- sobre quienes se comportaban de forma cívicamente reprobable. Proyecta sobre la comedia vieja el marco institucional y político romano desde el que Lucilio habría adaptado a Roma el género griego: la función pública de la comedia vieja se convierte así en la acción del censor y su 'parresía' en la libertas vigente en la República romana ${ }^{26}$.

Por otra parte, como han señalado algunos críticos (Freudenburg 2001, 17 y Hooley 2007, 48), la información que da Horacio sobre la comedia arcaica es errónea:

23 Horacio y Quintiliano solo mencionan a Ennio como poeta épico. De la dudosa alusión a Ennio en el rudis... auctor de Sat.1.10.66 nos ocuparemos más abajo.

24 Sobre la continuidad entre ambas fases ver: Muecke (2005), Labate (2009, 103-104) y Hooley (2007, 5-6). Somerstein $(2011,25)$, ve implícito en la afirmación de Quintiliano primus insignem laudem adeptus Lucilius (Inst.1.10.93) que Lucilio tuvo predecesores que no alcanzaron la gloria.

25 Freudenburg $(2005,6)$, cree que el silencio sobre Ennio se debe a que la satura enniana, una especie de experimento semigraecus, no tenía aún el componente fundamental de romanitas que adquiere el género con Lucilio.

26 Cicerón en Rep.4.11-12 ya le había aplicado el término técnico de la censura-notari-a la crítica practicada por los comediógrafos áticos. 
Aristófanes no se caracterizaba por perseguir a ladrones o adúlteros en general (vv. 3-5), sino por atacar a políticos y personajes de la vida pública ateniense identificados por sus nombres. Pero cabe dar otra interpretación de estos versos: más que de error, se trataría de manipulación interesada de la información, sin caer en una completa falsificación de los hechos. Como indica Rosen $(2012,28)$ tendríamos que poner la descripción de las víctimas contempladas aquí por Horacio en un nivel de abstracción más alto y veríamos que no se trataba tanto de señalar los verdaderos objetos de la crítica de la comedia vieja como de evocar su modelo de abuso personal de delincuentes y viciosos contemporáneos ${ }^{27}$. Horacio, al referirse a las víctimas de sus predecesores de manera imprecisa, en términos generales, evitaba que resultara chocante su pretensión de escribir sátira carente de abusos personales dentro de la tradición iniciada por aquellos, como afirma claramente un poco más abajo: his, ego quae nunc, / olim quae scripsit Lucilius, 56-6728.

De esta forma, limando las aristas de los ataques de sus predecesores, también su sátira reprogramada para los nuevos tiempos, podía entrar en la tradición, una sátira de la que los ataques nominatim de individuos relevantes quedan prácticamente excluidos: en esta misma sátira rechaza la acusación de haber practicado la censura personal y deja clara la renuncia de su obra a este tipo de agresividad. La plena libertas de expresión republicana ya no era posible en tiempos de Augusto ni siquiera para atacar a los enemigos del princeps, que, si bien no podía excluir la $l i$ bertas de su programa, tampoco podía permitir los abusos verbales personales porque dañaban su proyecto de pacificación y concordia ${ }^{29}$. Por eso la sátira horaciana, lejos de ser de agitación política, es sátira de conciliación e integración (Kennedy 1992, 26-29).

De todas formas, conviene que ya desde ahora recordemos que Horacio, con una muy bien medida ambigüedad no deja de permitirse ataques ad personam, aunque en la mayoría de los casos se trate de personajes de la generación anterior más bien poco significativos ${ }^{30} \mathrm{y}$, sobre todo, de poetastros despreciables. A ninguno de los satíricos romanos le faltó aspiración a la libertas, una característica del género bastante irrenunciable que no deja de ser evocada ni siquiera por los satíricos de época imperial, a pesar de no poder ni siquiera mencionarla abiertamente (Cortés Tovar 2006, 791-793 у 2007).

Tras afirmar la genealogía, pasa Horacio a criticar duramente a Lucilio por su estilo descuidado y por su prolijidad: recurriendo a la imagen crítica calimaquea del río que fluye cargado de lodo, señala que entran ganas de limpiar sus versos (cum flueret lutulentus, erat quod tollere uelles, 11) de las impurezas acumuladas en un proceso

$27 \quad$ El alcance de esta propuesta se enmarca teóricamente en un estudio más ambicioso sobre la poética de la sátira antigua (2007, 3-42) en el que Rosen intenta definir la sátira en la Antigüedad como género transhistórico, en cuyo marco se puede ver cómo obras de distintos géneros literarios y de autores alejados en el tiempo, como Hiponacte y Juvenal, tienen en común rasgos satíricos fundamentales.

28 Nasta (2003), en su afán por demostrar que Horacio está construyendo a Lucilio en Sat.1.4 como poeta yámbico, no tiene en cuenta esta reivindicación de Horacio de pertenecer a la misma tradición.

29 LaFleur $(1981,1820-25)$ señala que probablemente consideraba que tales abusos no solo dañaban la dignidad de las personas, sino también la del Estado. Delignon (2006, 82-91) trata detenidamente la actitud de Octavio-Augusto ante el 'franc-parler' y subraya la ambigüedad del princeps que mantiene la defensa de la libertas en su programa y propaganda y, al mismo tiempo, se muestra reticente ante el uso y abuso de la libertad de expresión en la confrontación política.

30 DuQuesnay (1984, 53-56) indaga sobre la identidad de los nombres que aparecen en las Sátiras de Horacio; pero ahora puede consultarse un repaso más detenido de las víctimas nombradas en Delignon (2006, 114-129). 
de creación más atento a la cantidad que a la calidad, pues Lucilio era capaz de dictar doscientos versos en una hora apoyado en un solo pie (9-13) ${ }^{31}$.

De acuerdo con esta crítica parece claro que, para Horacio, Lucilio no ha desarrollado todas las potencialidades del género ni lo ha llevado a la perfección: en 1 . 10.16-17 señala que su predecesor no ha imitado las virtudes literarias de la prisca necesarias para lograr la plena consolidación romana del género ${ }^{32}$, una tarea que él parece haberse propuesto llevar a cabo. Probablemente por eso, aunque lo considera cronológicamente el primero en cultivar el género, el inuentor del mismo (1. 10.47), no le concede aún la palma de primus en sentido cualitativo. Tal concesión tendrá que esperar al libro segundo, cuando ya Horacio se sienta seguro de haber afirmado sus opciones programáticas dentro de la tradición satírica luciliana; y aún así, como veremos más abajo, el texto en el que aparece no deja de ser ambiguo. De momento en los versos siguientes saca a escena a Crispín para seguir criticando a Lucilio de manera indirecta (1.4.13-21).

Este diatribista estoico, criticado anteriormente por su desmesurada locuacidad 1.1.122 y 1.3.139), reta al satírico a una competición poética para ver cuál de los dos consigue escribir más versos en el mismo tiempo. Crispín comparte los vicios de escritura de Lucilio: es también un garrulus y cumple aquí la función de sustituirlo en la confrontación con Horacio, que naturalmente rechaza el reto ${ }^{33}$. Gowers (2012, 149) señala un modelo aristofánico para esta sustitución: Aristófanes enfrenta a Esquilo y Eurípides en Ran.830-1527 para representar su propio enfrentamiento con Cratino; pero más cercano a 1.4.13-21 parece el choque entre el propio Aristófanes y Cratino representado en Eq.526-28 (Cucchiarelli 2001, 49-50), pues, como el comediógrafo, Horacio no se esconde detrás de ningún otro poeta; es a Lucilio al que sustituye por un contemporáneo suyo, seguidor del inuentor en su peor vertiente, de manera que parece estar insinuando que la deficiente imitación de la comedia arcaica llevada a cabo por Lucilio ha tenido como resultado que la sátira no haya avanzado hacia su perfección, pues sus imitadores en tiempos de Horacio solo copian de él los defectos.

Frente a Crispín, Horacio se auto-representa como poeta humilde de pocas y raras palabras, un poeta, que a diferencia también de Fannio desaforado divulgador de su propia obra (vv.21-22) ${ }^{34}$, no se atreve a recitar sus versos ante el vulgo, ya que todos le tienen miedo a la sátira y odian a los poetas, pues son conscientes de que, por su ambición, avaricia o adulterio, se merecen la censura satírica (vv.24-33). Horacio ha cambiado sutilmente los blancos de la sátira: ahora ya no se trata de perseguir a criminales sino a culpables de vicios menos graves, que aproximan la sátira de Horacio

31 Hunink \& Van den Broeck (2010) sugieren un significado escatológico para stans pede in uno, posición que correspondería a una '(des)composición’ diarreica.

32 Brink $(1963,158)$ cree que Horacio, con su crítica del estilo de Lucilio, lo está disociando de la tradición de la comedia vieja.

33 Este sería el primer garrulus al que se enfrenta Horacio. Algunos críticos creen que en la sátira hay otros parecidos a Lucilio como Caprio y Sulcio (1.4.65-67) y el scurra en el banquete (1.4.81-101) (Nasta 2003 y Ferris-Hill 2015). Pero el que está claramente caracterizado como garrulus es el poetastro pesado que lo asalta por la calle 1.9 (garriret, 13; garrulus, 33): tiene los rasgos de Lucilio (Schlegel 2005,108-126) en una sátira que, según Ferris-Hill (2011), imita a una de las piezas que componían el libro sexto del inuentor; de su análisis saca esta estudiosa la conclusión forzada de que ‘el pesado' es Lucilio.

34 Volverá a aparecer como autor de invectivas que tienen como blanco a Horacio en 1.10.80. 
más a la comedia nueva ${ }^{35}$ que a la comedia arcaica. Horacio, en sintonía con Cicerón, deja el castigo de los delitos mayores evocados en los vv.3-5 para los magistrados, porque como dice en 1.3.106 las leyes nacieron ne quis fur esset, neu latro neu quis adulter. Esta lista de delincuentes coincide con la de las víctimas de la comedia vieja de 1.4.3-5, a propósito de las cuales decía Cicerón: ciues a censore melius est quam a poeta notari (Rep.4.11) Los poetas no debían arrogarse tal función aunque las víctimas se lo merecieran ${ }^{36}$.

El giro que Horacio le da al género no consigue evitar que el vulgo, representado aquí por un interlocutor ficticio, muestre su hostilidad hacia el poeta satírico (vv.34$38)$ :
'faenum habet in cornu; longe fuge; dummodo risum excutiat, sibi non, non cuiquam parcet amico; et quodcumque semel chartis illeuerit, omnis gestiet a furno redeuntis scire lacuque, et pueros et anus'.

Lo describe como a un toro furioso, imagen propia de la agresividad del yambo ${ }^{37}$, que no deja a salvo de su sarcasmo ni a sus amigos, ni siquiera a sí mismo; y lo que es peor difunde sus escritos entre esclavos y viejas, que con sus cotilleos causan un daño social irreparable a sus víctimas.

Feeney (2009) ha estudiado cuidadosamente la recepción de Horacio y las formas en que el poeta la inscribe en su obra y reacciona ante ella; pero no incluye este texto entre los pasajes en los que Horacio proyecta a su lector. Es evidente que la reacción del interlocutor podía responder a la recepción de sus tres primeras sátiras, pero no parece hacer referencia concretamente a ellas ${ }^{38}$, sino a la tradición satírica anterior y contemporánea: la queja por la divulgación de los ataques satíricos responde al perfil de Fannio trazado antes (vv.21-22), y coincide con un pasaje de Lucilio en el que el interlocutor lo acusa de haberlo herido $(1089 \mathrm{~K})$ y de difundir maledicentemente sus asuntos privados en sus sermones $(1090,1091 \mathrm{~K})^{39}$. En cuanto a la acusación de agresividad yámbica y humor hiriente sería apropiada para los imitadores ramplones de Lucilio que habrían llevado la franqueza satírica - multa cum libertate- y el humor de su sátira a los niveles más bajos y groseros

35 Hunter (1985,486-487) señala que los nuevos objetos de la sátira nos llevan a esta: son los vicios cotidianos llevados al extremo los que la sátira critica y la comedia explota. Además un poco más abajo Horacio, al aproximar la sátira estilísticamente a la comedia (45-62), la considera sermo merus (48).

36 Horacio acepta la convención social vigente en su tiempo sobre el castigo de los delitos penalizados por la ley perfectamente expresada por Cicerón en el texto citado. Heldmann (1987,126-129) lo comenta con mayor detenimiento.

37 La imagen aparece en Calímaco, Iamb.1.78-19, donde Hiponacte responde a la acusación de que sus ataques son como los de un toro rabioso, y también Iamb.13.52-53, donde la rabia del poeta lo predispone a echar mano del cuerno. También en Horacio Epod.6.11-12 el poeta amenaza con recurrir a este arma (Gowers 2012,161)

38 Schlegel $(2005,41)$ no cree que la caracterización del poeta en vv. 34-38 pueda referirse a Horacio.

39 Los frags. corresponderían según Ferris-Hill (2015,141-142) a la sátira quinta del libro 30. Las coincidencias léxicas con 1.4 nos permiten afirmar que se trataba de una sátira programática: nunc, Gai, quoniam incilans nos laedis, uicissim, 1089K; gaudes, cum de me ista foris sermonibus differs, 1090K. Horacio en 1.4. 78 se defiende de la acusación de su interlocutor: laedere gaudes, en un contexto en el que se distancia de los que difunden sus escritos sin sentido de la oportunidad (vv.74-78). 
del ridiculum illiberale condenado por Cicerón como propio de la obscenidad del mimo y de la chocarrería del scurra ${ }^{40}$

El interlocutor traza el perfil de poeta satírico asentado en el horizonte de expectativas de los contemporáneos de Horacio, un perfil que con origen en la obra de Lucilio habrían alimentado después desafortunadamente sus seguidores, un horizonte de expectativas que Horacio rechaza y se empeña en romper con un nuevo tipo de sátira, sobre todo porque, si atendemos a las palabras del interlocutor, los Crispines y los Fannios han reducido la sátira a vehículo de sarcasmos y malediciencias indiscretas: la han convertido en un producto degradado, subliterario.

A continuación, en el resto de la sátira Horacio sigue rechazando las prácticas discursivas y poéticas responsables de los prejuicios sobre el género: las denuncias vocingleras de Caprio y Sulcio, delatores públicos (vv.69-70) $)^{41}$, la lectura inoportuna de sus escritos que algunos hacen en el Foro o los baños (vv.74-78), la búsqueda de aplauso para sus chistes del niger, que se convierte en el banquete en un scurra, indiscreto, mordaz y malicioso (vv.63-101) ${ }^{42}$. No seguirá su sátira a ninguno de estos modelos (vv.101-103), más atentos a hacer daño a sus víctimas que a intentar la mejora moral; para esta cuenta Horacio con el ejemplo de las charlas educativas de su padre (vv.105-129) en cuya configuración algunos críticos han visto la sombra de Demea, el padre educador en Adelphoe de Terencio (Leach 1971 y Citroni Marchetti 2004). De nuevo Horacio aproxima su sátira a la comedia nueva, sin que eso suponga el rechazo de la prisca, ya que traza una sutil continuidad entre ambas: los culpables de una y otra son dignos de censura (dignus describi, 3 y culpari dignos, 25) y su padre, aunque ponga el acento en los vicios y no en los viciosos también ac-

$40 \quad$ Para la presencia de la teoría peripatética del humor como trasfondo de esta sátira v. Dickie (1981,185-193). Cortés Tovar (1994,96-97) lee las intervenciones del interlocutor acusando al satírico de indiscreción y de agresividad yámbica (vv. 34-38, 78-79) sobre el trasfondo de los textos en los que Cicerón (Off.1.104; Orat.87-89 y De orat. 2.217-290), siguiendo la tradición peripatética, distingue cuidadosamente el ridiculum illiberale, propio de la intemperancia y el carácter inoportuno y grosero del scurra, y el liberale irónico, moderado y respetuoso con las personas y las circunstancias de lugar y tiempo.

${ }^{41}$ No compartimos la idea de que Caprio y Sulcio sean autores de libelos que divulgan por las calles, como sostienen Freudenburg (2001), Nasta (2003) y Ferris-Hill (2015). Si bien es verdad que, a través de libelli (v.66), aparecen relacionados con los libellos del propio poeta (v.71), nos inclinamos por tomar la primera aparición de la palabra en el texto como 'acta de acusación' (Gowers 2012, 169, recoge todas las acepciones del término), porque creemos que Horacio se está refiriendo aquí no solo a sermones escritos como los suyos (vv.71-74), cuya difusión mantiene bajo riguroso control, y a los versos de poetastros que sin ningún sentido de la oportunidad los leen en el foro y en los baños (74-78), sino también a dos tipos de discursos sociales, que podrían inspirar el tipo de sermo que él rechaza: el de los delatores públicos, ya comentado, y el del scurra que aparece más abajo (vv.81-101).

Por su parte Ruffell (2003, 40-42) pone los vv. 65-74, que denuncian los versos abusivos y su difusión pública, en el contexto de la producción popular de invectivas, aportando Catulo 37.1-10, como un posible intertexto.

42 La crítica comúnmente distingue entre los vv.81-85 dedicados a retratar al niger y la presentación de este en acción en los versos siguientes (vv.86-101); y algunos críticos le atribuyen los primeros versos a un interlocutor (Voit 1980; Hunter 1985). Nos inclinamos por atribuirle todo el pasaje al satírico en su conjunto, pero diferenciando los vv.81-85 del resto: estos versos serían una cita irónica del código de conducta del niger, que critica maliciosamente al ausente y cuenta lo que no ha visto y los secretos que le han confiado con tal de hacer reír y de alcanzar famam dicacis (v.83). El tono paródicamente oracular del último verso (Courtney 2013, 92) denuncia la ironía: hic niger est, hunc tu, Romane, caueto. El relato que sigue sobre la conducta del scurra en el banquete pone de manifiesto que se comporta como un niger (hic nigrae sucus lolliginis, 100), porque hace un uso abusivo de la libertas y porque respetando hipócritamente la letra pero no el espíritu del código hace maliciosas insinuaciones sobre el amigo ausente (Cortés Tovar 1994, 97-98). 
túa como un censor: exemplis uitiorum quaeque notando (v.106) ${ }^{43}$. Esta continuidad entre ambos tipos de comedia, es la misma que Horacio intenta establecer entre él y Lucilio: en ambos casos se pasaría de una libertas y agresividad mayores a una crítica más templada e irónica ${ }^{44}$. De todas formas, el modelo dominante, y que termina por imponerse en el programa satírico de Horacio en 1.10, es el de la comedia vieja, si no en su vertiente de invectiva, sí en el humor y en el estilo. La entrada de la comedia nueva como referente genérico en 1.4 parece un recurso del poeta para fortalecer su autodefensa y subrayar su distancia de Lucilio y, sobre todo, de sus extraviados seguidores, una estrategia que en cualquier caso no le impide seguir proclamándose sucesor de la prisca y de Lucilio e incluirse en su tradición.

En la 1.10 Horacio prosigue el camino abierto para su nueva sátira en 1.4. En un libro cuidadosamente construido para que el lector perciba en su lectura lineal el avance de las relaciones dinámicas que las sátiras mantienen entre sí (Zetzel 1980, 63-64), la 1.10 se apoya en las supuestas reacciones que la 1.4 habría suscitado en los lectores, concretamente en los admiradores de Lucilio, que con toda probabilidad rechazarían la dura crítica de Horacio a su estilo. No olvidemos que Lucilio fue un poeta muy admirado en su tiempo y en la generación siguiente. Basta con leer las alabanzas que le dedica Cicerón: más de una vez le llama doctus et perurbanus (De orat.1.72 y 2.25) ${ }^{45}$. Horacio era consciente del éxito de su predecesor, de modo que podía proyectar en 1.10 de manera convincente la reacción negativa de los lectores a las críticas vertidas por él contra Lucilio en 1.4. Pues bien, a esa reacción responde en esta segunda pieza programática ${ }^{46}$.

La sátira empieza abruptamente (nempe) como si estuviera retomando un sermo interrumpido:

Nempe incomposito dixi pede currere uersus

Lucili. Quis tam Lucili fautor inepte est

ut non hoc fateatur? at idem, quod sale multo

urbem defricuit, charta laudatur eadem.

nec tamen hoc tribuens dederim quoque cetera; nam sic

et Laberi mimos ut pulchra poemata mirer.

Y hasta tal punto es esta la sensación que parece buscar Horacio que no cambia sustancialmente lo que había dicho antes: reconoce y confirma la crítica a la descuidada composición poética de Lucilio -durus componere uersus (1.4.7), incomposi-

43 Citroni Marchetti $(2004,19)$ señala las diferencias entre ambos tipos de comedia y estudia el texto de Horacio con referencia no solo a Adelphoe sino también a textos filosóficos; su padre le enseña una forma nueva de hacer sátira.

44 La suma de ambos modelos de comedia para la sátira y la evolución paralela en ambos géneros ha sido señalada por Cucchiarelli $(2001,43-45)$, Hunter $(2009,101)$ y Ferris-Hill $(2015,7)$.

45 Frente al gran éxito de Lucilio, Horacio traza una imagen de él en la que aparece despojado de muchas de sus virtudes. Como dice Hooley $(2007,49)$ Horacio no fue justo con su predecesor, pues ignora su erudición, su sofisticación cultural, su experimentación e inventiva métrica y sus estudios sobre composición poética. El éxito de Lucilio seguía vivo en época flavia: Quintiliano da testimonio de que aún entonces había quienes le consideraban no solo el mejor poeta satírico, sino incluso el mejor poeta romano de todos los tiempos (Inst.10.1.93).

46 Feeney $(2009,21-25)$ insiste en que Horacio en 1.10 siempre se refiere a sus lectores, ya que en vv. 38-39 afirma que no hace recitationes públicas. Pero, a pesar de su reiterada afirmación de que solo las leía en un círculo restringido, el mismo nos da cuenta de las filtraciones que desde el principio dieron lugar a su difusión entre un público más amplio (1.4.92). 
to dixi pede currere uersus (1.10.1) - y también sus anteriores alabanzas -facetus,/ emunctae naris (1.4.6-7) y at idem, quod sale multo urbem defricuit, charta laudatur eadem (1.10.3-4). Los estudiosos han señalado diferencias entre las afirmaciones de 1.4 y las de 1.10, especialmente en el caso de las alabanzas. En 1.10 Horacio precisa más el motivo por el que había alabado a Lucilio: por la función saludable para Roma que cumplía su sátira, siguiendo los pasos de Aristófanes (Gowers 2012, 312); pero la sustitución de multa cum libertate combinada con facetus (1.4.5), por multo...sale (1.10.3), introduce una ambigüedad que podemos explicar si tenemos en cuenta cómo se seguía desarrollando el sermo en 1.4 después de sus primeros versos, concretamente en el pasaje dedicado al niger (1.4.81-103). Horacio criticaba los excesos de dicacitas (v.83) y de libertas de este personaje, provocados por Liber (vv.88-89), excesos que él prometía no imitar en su sátira (vv.101-103); de manera que podemos interpretar sale... multo como una referencia intratextual a ese pasaje que rebaja la alabanza expresada por facetus -término asociado al humor no agresivo (Cic.Off.1.194; De orat.2.264)- y subraya la falta de contención en el uso del chiste corrosivo (sale multo...defricuit), lo que le sirve de punto de partida para la crítica del humor de Lucilio en los versos siguientes: no basta con hacer reír como lo hacen los mimos de Laberio (1.10.5-7) ${ }^{47}$. Así que sigue manteniendo la alabanza a Lucilio por haber seguido a la prisca en su acción censora, pero precisa y profundiza la crítica por no haberla seguido en todo lo demás (cetera, 5), en lo que Horacio consideraba adecuado para las exigencias estéticas de su tiempo:
est breuitate opus, ut currat sententia neu se
impediat uerbis lassas onerantibus auris;
et sermone opus est modo tristi, saepe iocoso,
defendente uicem modo rhetoris atque poetae,
interdum urbani parcentis uiribus atque
extenuantis eas consulto. ridiculum acri
fortius et melius magnas plerumque secat res.
Illi, scripta quibus comoedia prisca uiris est,
hoc stabant, hoc sunt imitandi; quos neque pulcher
Hermogenes umquam legit neque simius iste
nil praeter Caluum et doctus cantare Catullum. (1.10.9-19)

Este manifiesto del género reúne todas las virtudes que Lucilio no tenía: brevedad frente a la prolijidad de aquel, avance ágil (ut currat sententia) frente a los versos cargados de lodo, ligereza y una sabia combinación de tonos: junto al 'spoudogéloion', los tonos alternativos del rétor o del poeta o del que maneja con habilidad la ironía y atenúa la violencia cuando es necesario, porque «el humor resuelve los asuntos difíciles mejor y con más fuerza que la acritud». Para esta variedad, que afirma las ventajas del carácter serio-cómico de la sátira, el modelo se encuentra en los poetas de la comedia arcaica; de modo que insiste en la necesidad de imitarlos en esto: hoc stabant, hoc sunt imitandi (v.17). Una vez más, mientras la disociación de Lucilio de la comedia arcaica se hace de manera ambigua y casi imperceptible, la fuerza de la crítica se vierte contra otros poetas, Hermógenes y el 'simio', que no

47 Delignon (2006, 232-33) examina detenidamente en Cicerón y Quintiliano las distinciones terminológicas y la teoría retórica del humor que subyace a este pasaje. 
alcanzan los estándares de calidad exigidos porque no han leído a Aristófanes y los demás comediógrafos áticos: solo saben imitar a los neotéricos Calvo y Catulo. La referencia repentina a estos dos poetas produce perplejidad y nos obliga a preguntarnos cómo pueden defender los imitadores de los neotéricos a Lucilio, criticado por Horacio desde una perspectiva calimaquea, si se supone que los neotéricos también seguían la doctrina poética de Calímaco. El preámbulo, que un interpolador probablemente contemporáneo de Horacio le añadió a esta sátira, nos ayuda a recuperar el eslabón perdido.

Los primeros versos (1-3*) del proemio espurio en el que Horacio promete demostrar fehacientemente los defectos de Lucilio, presentan a Valerio Catón como defensor y editor de sus sátiras, que se esfuerza en corregir sus versos male factos, $y$, por tanto, como oponente de Horacio ${ }^{48}$. Tenemos aquí un testimonio claro de que los neotéricos con su decano a la cabeza apreciaron a Lucilio; por eso Horacio puede sustituir a Crispín y a los otros imitadores directos de Lucilio de 1.4 por los imitadores de los neotéricos, que, como aquellos, son poetastros despreciables merecedores de los ataques nominales del satírico: Hermógenes Tigelio, que ya aparecía como músico en 1.3.129 y el 'simio', posible mote de Demetrio, aparecerán de nuevo más abajo (vv.78-80). Estos son los Lucili fautores a los que sigue respondiendo en los versos siguientes.

Horacio les atribuye los argumentos que a él le interesan para seguir definiendo su sátira entre la adhesión al calimaqueísmo y la afirmación de la romanitas. El defensor de Lucilio alaba como gran logro estilístico de este la mezcla de palabras griegas con las latinas, porque así prestaba más suauitas -término característicamente neotérico- a su sermo, una práctica que el satírico en su respuesta no considera ni «difícil ni admirable» por estar al alcance del rodio Pitoleonte o de cualquier canusino bilingüe. Frente a la mezcla luciliana, Horacio defiende la latinitas pura y recurre a la convención del sueño de inspiración poética para justificar la completa romanitas de su obra: Quirino, se le presenta en sueños y le aconseja que deje de escribir graecos...uersiculos (20-35).

La mezcla de las dos lenguas no parece que fuera un principio central de la poética neotérica, ni de la de Calímaco, pero no era rechazada por ellos ${ }^{49}$, mientras que Horacio sí la rechaza: defiende exactamente la posición contraria, la pureza lingüística, de modo que se estaría apartando aquí de la doctrina calimaquea, de la que defiende la breuitas, el cuidado artístico y la exclusividad de los lectores. Horacio acepta el calimaqueísmo y al mismo tiempo afirma su independencia con respecto a él: adopta de la tradición calimaquea el sueño iniciático, como Virgilio en Ecl.6.3-5, pero sustituye a Apolo, por Quirino que habla en latín e invita al poeta a llenar su poesía de temas romanos ${ }^{50}$. Horacio critica el calimaqueísmo superficial y defiende un tipo de imitación más profundo, en el que, siguiendo la recomendación de Ca-

48 Cucchiarelli $(2007,177)$ dice que el prólogo parece demostrar que el debate se consideraba urgente y que Horacio estaba casi profesionalmente empeñado en él.

49 Scodel $(1987,206-210)$ comenta que Calímaco en el Iamb. 13 se defiende de los críticos que lo acusan de utilizar un dialecto mezclado.

50 Zetzel (2002) sigue bastante a Scodel en la tesis de que Horacio adapta el calimaqueísmo a las necesidades romanas de su poesía, pero añade interesantes comentarios sobre las actitudes diferentes de Virgilio en Eglogas y Horacio en Sermones hacia el alejandrinismo y analiza en algunas sátiras $(1.5 ; 1.2)$ la actitud crítica de Horacio que se manifiesta en parodias, ironías y revisiones de los principios calimaqueos que para él debían adaptarse al contexto romano y a los temas romanos del mundo real. 
límaco de imitar a los clásicos griegos de forma creativa, no intenta reproducirlos, sino romanizarlos con entera originalidad.

El contexto, en el que aparece esta afirmación de Horacio de la romanitas de su sátira, arroja dudas sobre la romanitas de la sátira de Lucilio, que mezclaba palabras griegas con las latinas. Horacio no niega explícitamente la romanitas fundamental de la obra de Lucilio subrayada constantemente por sus estudiosos ${ }^{51}$, pero una vez más manipula la historia del género para aparecer él como el primero en lograr para la sátira la pura latinitas y la perfección artística que le permitiera integrarse en el canon clásico junto a los poetas que habían conseguido cultivar en latín los géneros griegos sin ceder en excelencia ante sus modelos:
arguta meretrice potes Dauoque Chremeta
eludente senem comis garrire libellos
unus uiuorum, Fundani; Pollio regum
facta canit pede ter percusso; forte epos acer
ut nemo Varius ducit; molle atque facetum
Vergilio adnuerunt gaudentes rure Camenae:
hoc erat, experto frustra Varrone Atacino
atque quibusdam aliis, melius quod scribere possem,
inuentore minor; neque ego illi detrahere ausim
haerentem capiti cum multa laude coronam. (1.10.40-49)

Este canon se estaba formando en los primeros años 30 y no estaba completo, puesto que debían incorporarse aún géneros introducidos en Roma por los neotéricos: la poesía bucólica y la lírica, la elegía y el yambo, los géneros que daban expresión a la subjetividad de los individuos ${ }^{52}$. Horacio, que en estos mismos años estaba escribiendo el libro primero de las Sátiras, justifica su elección genérica alegando que había en el canon un hueco vacío para este género debido a que las tentativas llevadas a cabo Varrón Atacino y «algunos otros» en el cultivo de la sátira habían fracasado. Parece que, a pesar de su aparente modestia, Horacio está afirmando que solo con él ha alcanzado el género el 'telos', igual que los demás géneros mencionados habían sido llevados a su culminación canónica a manos de los demás amigos del Círculo de Mecenas. Pero corrige de nuevo esta orgullosa afirmación declarándose inuentore minor e incapaz de arrebatarle a sus predecesor su merecida gloria (vv.4849). ¿Cómo debemos interpretar estas palabras? Después de que Horacio haya confirmado sus críticas a Lucilio y lo haya aproximado a los mimos de Laberio, no dejan de sorprendernos.

Horacio es un maestro de la ambigüedad, pero también lo es de la sutileza y la ironía. No creo que nos encontremos simplemente ante una manifestación convencional de una modestia sobre el mérito literario propio generadora de ambigüedad; me inclino más bien por la ironía. El pasaje que acabamos de citar se abría en los vv.

51 Freudenburg 2005, además de subrayarla, la explica como una reacción nacionalista de Lucilio ante la expansión imperialista de Roma en el s. II, que ponía en peligro la identidad romana.

52 Todos estos géneros ya cultivados por lo neotéricos se consolidarían y recibirían su forma clásica en manos de los poetas augústeos. Como dice Citroni $(2003,182)$, Horacio formaba parte de una generación de poetas que se dieron cuenta de que había que superar la actitud de desafío de los neotéricos y que era necesario proponer al público romano obras y géneros capaces de confrontarse con los canónicos griegos sin renunciar a los valores romanos. 
36-39 con el rechazo horaciano de la épica encarnada por los Annales Belli Gallici de Furio Bibáculo, del que dice muy expresivamente recordando sus críticas al estilo de Lucilio que ha cubierto de lodo la cabeza del Rin -diffingit Rheni luteum caput, 37-. Furio, un neotérico que ha fracasado en el cultivo de la épica, abre el pasaje, Varrón Atacino, otro neotérico, que también ha fracasado pero en la escritura de la sátira lo cierra, frente al éxito de los poetas del nuevo canon; ambos poetas serían admiradores de Lucilio y responsables de la corona que el inuentor lleva «adherida a su cabeza» ¿Estas asociaciones indirectas no pretenden arrojar irónicamente dudas sobre la laus a Lucilio, al que tanto pretende respetar Horacio?

Por eso a continuación vuelve Horacio a evocar las críticas lanzadas en 1.4 contra Lucilio exagerándolas aquí (vv.50-51), pues ya no solo es que hubiera que «quitarle cosas» a su obra (erat quod tollere uelles, $1.4,11$ ) sino que habría que eliminar más que las que quedarían después de la poda (plura quidem tollenda relinquendis, 1.10.51). Aún así se disculpa por sus críticas ya que en realidad no hace sino seguir el modelo de Lucilio, que también criticó a Accio y Ennio sin ponerse por encima de ellos: cum de se loquitur non ut maiore (v.55) ¿De ahí que también él se considere a sí mismo inuentore minor? Veamos el texto:

\author{
fuerit Lucilius, inquam, \\ comis et urbanus, fuerit limatior idem \\ quam rudis et Graecis intacti carminis auctor \\ quamque poetarum seniorum turba: sed ille, \\ si foret hoc nostrum fato delapsus in aeuum, \\ detereret sibi multa, recideret omne quod ultra \\ perfectum traheretur, et in uersu faciendo \\ saepe caput scaberet uiuos et roderet unguis (64-71)
}

Por lo que dice aquí, Lucilio podría haber hablado de sí mismo «como superior», ya que ahora Horacio pone por fin las alabanzas y críticas a su predecesor en perspectiva histórica y reconoce que Lucilio fue un adelantado para su época: «más pulido» que los poetas más viejos. En cuanto al propio Horacio, aunque solo sea porque en la edad en la que le ha tocado vivir tiene que responder a exigencias estéticas más estrictas, está claro que no se considera inferior a Lucilio, de manera que podemos confirmar el valor irónico de inuentore minor, si bien la ironía no cancela por completo el significado superficial, porque minor no significa solo 'inferior', sino que referido al tiempo podía usarse también como 'más joven', de manera que le permitía a Horacio confirmar la prioridad de Lucilio en la tradición a la que él mismo se suma. Además su predecesor habría elaborado con mayor cuidado su obra si su vida se «hubiera prolongado» hasta época augústea, de manera que la perspectiva histórica en la que ahora pone su crítica y la ironía y ambigüedad de inuentore minor le permiten afirmar al mismo tiempo distancia y proximidad con respecto a Lucilio.

En relación con los inicios del género este texto también plantea otro problema: ¿a quién se refiere con rudis et Graecis intacti carminis auctor? ¿quién es este auctor de un género no tocado por los griegos? Auctor se referiría al 'originator', al que lo inició frente al inuentor que lo 'estableció', que le dio forma ${ }^{53}$. La crítica ha dado

53 V. Gowers $(2012,332)$ que sigue en estas diferencias terminológicas a Van Rooy $(1965,53)$. Este cree que Horacio reconoce a Ennio como el fundador de la sátira latina (32). 
diversas respuestas a esta cuestión: podría referirse a Ennio, sobre cuya producción 'satírica' ha mantenido silencio, o a un poeta anterior que no llegó a darle forma definida al género. Quintiliano, como hemos señalado antes, al afirmar primus insignem laudem adeptus Lucilius puede estar pensando en otros poetas que cultivaron el género sin éxito, pero difícilmente en Ennio al que después asocia por su polimetría con las menipeas de Varrón. De manera que me parece más probable que se refiera a algún poeta arcaico desconocido que experimentaría con la sátira sin resultados apreciables.

Por otra parte, con la referencia a ese auctor de un género «no intentado por los griegos», Horacio está afirmando la romanitas del mismo, su origen romano, en perfecta sintonía con la reivindicación de la latinitas pura y el sueño de Quirino, antes comentados, afirmaciones todas de acuerdo con la reivindicación de Quintiliano: satura quidem tota nostra est. Partiendo de estos pasajes podemos desactivar mejor la debatida contradicción entre Quintiliano y Horacio, que hasta recientemente se intentaba resolver teniendo en cuenta solamente Sat.1.4.1- $7^{54}$. No es necesario recurrir a la interpretación forzada de la posición de la comedia arcaica y de la sátira en las listas de géneros griegos y latinos de Quintiliano: es verdad que en la lista de los griegos no aparece la sátira ni en la de los latinos la comedia vieja, pero esto no supone un 'matrimonio implícito' como propone Harris-Hill $(2015,2)$, porque el paralelismo entre los lugares que ambos ocupan en sus respectivas listas (comedia arcaica entre lírica y tragedia, sátira latina entre la elegía y el yambo) no resulta convincente $^{55}$. Más interesante para refutar la contradicción me parece la explicación que da Ferris-Hill de la famosa afirmación de Quintiliano siguiendo a Van Rooy: en vez de poner el acento en quidem $^{56}$, lo pone en tota como predicativo de satura: esta «en su totalidad», con la combinación de elementos que la constituyen en la forma en que la cultivaron los poetas satíricos romanos, es romana, no tiene equivalente entre los griegos ${ }^{57}$. De manera que la afirmación del carácter romano de la sátira se encuentra tanto en el poeta (1.10) como en el crítico (Qvint.Inst.10.93) ${ }^{58}$, con la sola diferencia de que este le concede a Lucilio el título de primus en sentido cualitativo y Horacio, como hemos indicado, no lo hace aún en el libro primero: es su obra la que logra para el género la culminación canónica.

Si nos atenemos a su historia, después de Lucilio solo han cultivado la sátira sin arte ni contención sus mediocres seguidores y los imitadores de los neotéricos, a los que él ataca y descalifica en 1.4 y 1.10. Pero conviene que examinemos, junto a esta intrahistoria horaciana, otros relatos históricos sobre la sátira romana postluciliana.

En los años de inestabilidad política de finales de la República proliferaron los libelos, panfletos y sátiras. La libertas de expresión luciliana fue interpretada en clave política como un reflejo de la libertas republicana y utilizada como arma política por todos los bandos (Cortés Tovar 2005, 787), especialmente por los pompeyanos, ya que Lucilio era tío-abuelo de Pompeyo Magno. La mayoría de los estudiosos de

\footnotetext{
Sobre el largo debate generado por esta contradicción, v. Ferris-Hill (2015, 1-3).

Ya lo habían señalado Van Rooy (1965, 122; Labate 2009, 102; Hunter 2009 96-97).

Freudenburg $(2005,2)$ subraya el valor de alivio que supone ese quidem: ¡por fin un género enteramente romano! La explicación se remonta de todas formas a Hendrickson $(1927,58)$.

58 Aunque sin referirse al debate de la contradicción entre los textos de Horacio y Quintiliano, algunos críticos han señalado la afirmación de romanitas en estos pasajes y su aproximación a la afirmación nacionalista de Quintiliano (Feeney 2002 y Cucchiarelli 2007).
} 
la obra de Lucilio y de los escritores de sátira o invectiva de los que tenemos noticia, según DuQuesnay (1984, 29-31), fueron partidarios de Pompeyo o anticesarianos. Suetonio nos informa de que Curcio Nicias, seguidor de Pompeyo, escribió libros sobre las sátiras de Lucilio, (Gramm.14.4), probablemente comentarios gramaticales (Kaster 1995, 176); también su liberto Pompeyo Leneo las estudió con Lucio Arquelao ${ }^{59}$, y escribió, después de la muerte de Pompeyo, una salvaje invectiva contra Salustio, quizás en hexámetros, por haber criticado a su señor (Gramm.15.2). Gayo Trebonio, amigo de Cicerón y partícipe de la conjura contra César, escribió en el 44 a. C. un poema caracterizado por una desenfrenada libertas luciliana, que justifica apelando a la turpitudo de Marco Antonio, su víctima (Cic.Epist.12.16.3). A la producción de estos satíricos hay que añadir las invectivas de los neotéricos ${ }^{60}$ : Catulo, Calvo, Pitolao y Furio Bibáculo, que admiraron el espíritu de Lucilio, si no su estilo, e insultaron nominalmente a políticos contemporáneos especialmente a César que, a pesar de todo, los trató con clemencia (Svet.Iul.73) ${ }^{61}$.

Pero no todos fueron anti-cesarianos. El cuadro, como sostiene Rufell 2003, 39), es más complejo: Valerio Catón, cuidadoso editor de Lucilio (1.10.2-3*), que escribió un libellus en verso llamado probablemente Indignatio, no parece haber tenido una adhesión política fuerte. Varrón Atacino, autor de sátiras (1.10.46), posiblemente militaba en el bando cesariano, pues escribió un poema épico sobre las campañas galas de César. Además, la tradición luciliana no se identificaba solo con la invectiva política; la autobiografía y la erudición tuvieron también su peso en este grupo dispar de literatura satírica: Sevio Nicanor compuso una satura en hexámetros influida por la vertiente confesional de la sátira de Lucilio (Svet.Gramm.5); y Lucio Abucio, mencionado por Varrón en Rust.3.2.17, es caracterizado como doctus y sus libros como luciliano charactere. También el mismo Varrón escribió cuatro libros de sátiras, pero no sabemos nada sobre su contenido y fecha de publicación (Coffey 1989, $63)^{62}$. Por otra parte, para Ruffell, ningún grupo ni poeta se adhirieron enteramente a la tradición de Lucilio ni a la de la sátira; no olvidemos que este estudioso tiene muy en cuenta las tradiciones popular y culta de la invectiva. De manera que cree que la historia de la sátira postluciliana es oscura y no está claro que pueda llamársele 'tradición'; muy probablemente la sátira en tiempos de Horacio sería vista como un fenómeno inestable: las invectivas de los poetas mencionados no siempre estaban escritas en hexámetros; recuperaban a veces los senarios y septenarios que Lucilio había utilizado en sus primeros libros (Ruffell 2003, 62).

Desde el punto de vista literario todos los exponentes tardo-republicanos de la sátira tienen en común que solo se han aproximado al género de manera puntual, en determinadas ocasiones, no lo han cultivado de forma sistemática. En efecto el relato sobre el género que nos permiten reconstruir los pocos datos aportados por los his-

59 Así lo afirmaba Leneo con orgullo según el testimonio de SvET.Gramm.2.2, que en el mismo lugar recoge el testimonio de Valerio Catón de haber sido discípulo de Vetio Filocomo: ambos gramáticos habrían sido al menos una generación más jóvenes que su amigo Lucilio (Kaster 1995, 67)

${ }_{60}$ Calvo, Catulo y Pitolao atacaron a César en epigramas, versiculi y carmina maledicentes (Svet.Iul.73 y 75). Furio Bibáculo aparece también, junto a Catulo, como autor de versos insultantes contra los Césares en TAC. Ann.4.34.5.

${ }_{61}$ Rudd $(1966,85)$, LaFleur $(1981,1803-806)$ y Coffey $(1989,63-64)$ también nos ofrecen un buen repaso de todos estos autores de sátira e invectiva.

62 Sobre las conjeturas (en desacuerdo) con respecto las inclinaciones políticas de Varrón v. bibliografía citada por LaFleur $(1981,1805)$. 
toriadores (SveT.Iul.7.75 y Gramm.5.1.14 y 15 y TAC.Ann.4.34.5), coincidentes en parte con los de Horacio $^{63}$ no puede ser considerado una 'historia' de la sátira, porque en él no se observa atención a la continuidad o evolución sostenida en el cultivo de esta forma literaria. Pero en cualquier caso constituye un panorama histórico, que no desautoriza por completo a Horacio, un panorama que para él tuvo que ser interesante, porque podía servirle para trazar la historia de la tradición del género que le interesaba: la invectiva no podía imponerse porque estaba infectada por la política y por la subliteratura. Rufell sostiene que la invectiva popular y la de la élite letrada, la de los neotéricos, no tenían fronteras firmes, que se contaminaban recíprocamente; y lo argumenta analizando las concomitancias entre Catulo y Calvo y los libelos populares. Lo que hace Horacio es segregar toda esta producción de libelos y pasquines, ponerlos al margen de la literatura, trazar un cordón sanitario en torno a la sátira literaria según él la concibe. De ahí los abusivos ataques, que, en contradicción con su propia poética de 1.4, lanza contra poetas y poetastros.

En este aspecto 1.10 supone un avance con respecto a 1.4: entre los seguidores de Lucilio no se encuentran ya solo diatribistas estoicos, sino los propios neotéricos y seguidores de estos como Hermógenes y el 'simio', que aparecerán de nuevo más abajo en el pasaje dedicado a los lectores:

men moueat cimex Pantilius aut cruciet quod uellicet absentem Demetrius aut quod ineptus Fannius Hermogenis laedat conuiua Tigelli? (78-80)

Los poetas nombrados aquí, despreciados como lectores y críticos (contemptis aliis, 77), están caracterizados como el niger de 1.4: Demetrius despelleja al satírico por detrás, igual que el niger criticaba con mordacidad al ausente (absentem qui rodit, 1.4.81), y Fannio, conuiua de Hermógenes, lo hiere. Las referencias intratextuales al pasaje de 1.4 son muy evidentes: laedere, 78 ; absentem, 81 ; ineptus, 91; convictor, 96. Son poetas, que sacan su inspiración de donde no deben: del comportamiento del scurra en el banquete. Horacio ha sido objeto de sus ataques y les devuelve el mordisco nombrándolos como lectores despreciables frente a los que él desea para su obra: Plotius et Varius, Maecenas Vergiliusque ... (v.81ss.)

Parece claro que Horacio quiere darnos la impresión de que el género no ha conseguido evolucionar como es debido a partir de Lucilio. Ha sido cultivada la vena yámbica de este, no la satura con su forma fija y su mezcla de tonos y propósitos. De esto no cabe deducir que Horacio desprecie a los buenos poetas yámbicos; simplemente no están en la tradición de la sátira, a la que intentó darle continuidad Varrón Atacino, entre otros. Su falta de éxito le ha dejado a él el campo libre para seguir el mismo camino y a estas alturas, al final de un libro completo de sátiras, ya puede afirmar que ha conseguido desarrollar todas sus potencialidades (1.10.40-49).

Podemos hacer ahora un alto en el camino para resumir los hitos de la historia de la sátira según Horacio:

1. Su inuentor Lucilio toma inspiración en el modo de censura de la comedia arcaica y la adapta a Roma, pero no consigue llevarla a la perfección porque

63 Como LaFleur $(1981,1804)$ señala, Calvo, Catulo, Pitolao y Furio Bibáculo son mencionados como autores de invectivas por los historiadores y criticados por Horacio en 1.10 . 
de la comedia solo toma la libertas y el humor caústico, no las virtudes de su 'spoudogéloion', del que Horacio destaca el humor irónico (ridiculum).

2. En la sátira postluciliana la libertas y la acerbitas se ponen al servicio de los ataques políticos y favorecen la proyección sobre Lucilio de una imagen sesgada, en la que se destaca su tendencia a la invectiva. A Horacio le viene muy bien esta imagen simplificadora de su predecesor y la adopta para definir mejor los perfiles nuevos de su propia sátira, la que exigen las nuevas condiciones políticas y estéticas; de manera que hábilmente retrata a sus oponentes y adversarios como esos poetas y poetastros autores de libelos y pasquines que deben quedar fuera de los límites del género: se trata de los seguidores de Lucilio y de los neotéricos. El género se ha desviado de su modelo griego más prestigioso y se ha estancado en una multiplicidad de formas yámbicas: la historia de la sátira se ha interrumpido.

3. Horacio, que se incluye desde el principio en la tradición de Lucilio y la comedia arcaica, se propone devolver la sátira al camino perdido por los imitadores degradados de Lucilio, aunque adaptando su modo a las condiciones políticas de su tiempo que no admiten ni el ‘onomastí komodeín' ni el exceso de libertas. Pero no se presenta como el único que ha intentado recuperar el camino perdido; introduce un estadio intermedio, una especie de nueva fase de experimentación previa a su logro: la ocupada por los intentos frustrados de Varrón Atacino y otros, frustración que le permite erigirse en canonizador del género en 1.10.46-47.

De esta forma, con esta historia en dos tiempos (un primer comienzo brillante pero fallido en parte por no haber evolucionado correctamente -Lucilio y sus seguidores- y otro, el correspondiente al clasicismo augústeo con su propia fase de pruebas frustradas -Varrón Atacino y otros- y éxito final en su propia obra) Horacio consigue ser también en este género el primus en el sentido cualitativo, un título que, por muchas protestas de reconocimiento de los méritos de Lucilio que haga, no le concede a este. Frente a la historia de otros géneros poéticos en las que, como decíamos al principio, los poetas latinos se proclaman al mismo tiempo primi en sentido cronológico y de excelencia, la de la sátira se ajusta a la teoría de la evolución adoptada y seguida por Cicerón.

Con la inclusión de la sátira en el canon de la poesía augústea podríamos dar por terminado el estudio de la historia horaciana del género en un sentido estrictamente literario, pero descuidaríamos una parte de esta historia que Horacio desarrolla en su última sátira programática, la 2.1: el contexto político que le sirve de marco, los posibles choques del género con las leyes y las relaciones del satírico con el poder político.

La 2.1 como ha señalado la crítica, es tanto un cierre del libro primero como un proemio del segundo libro (Rudd 1966, 124; Labate 2009²,107 [1996]) $)^{64}$, una pieza de transición.

En los primeros versos (1-4) Horacio se hace eco de los dos tipos de reacciones críticas radicalmente opuestas que su libro 1 ha provocado: unos ven su sátira como demasiado dura, ultra legem, y otros lo acusan de haber ablandado el carácter incisivo del género. De modo que le consulta a un amigo jurista, Trebacio Testa, sobre el

64 Hay quien subraya más su condición de proemio, por anunciar un cambio narratológico radical con respecto al libro 1 (Freudenburg 2001, 71-74) y quien la considera el cierre del libro anterior (Cucchiarelli 2001, 114). 
camino que debe seguir (quid faciam? v. 5) y es así como la sátira adopta la forma de diálogo entre ambos.

Trebacio, sin duda, toma ultra legem en sentido jurídico -podía referirse también a la ley del género-, pues en todas sus intervenciones trata de apartar a Horacio del peligro legal que conllevaba la escritura de sátira agresiva y personal, como si el satírico se dispusiera a escribir ese tipo de sátira. Si lo hace -le advierte Trebacio-, en cualquier caso conseguirá por lo menos impopularidad generalizada (v.23) ${ }^{65}$ o que algunos de sus amigos importantes lo reciba con frialdad (vv. 60-62); para no irritar a nadie, más le valdría cantar las hazañas del César invicto (10-12) o su magnanimidad y sentido de la justicia, como hizo Lucilio con Escipión (16-17). De esta forma empieza a establecerse un paralelismo entre las relaciones de amistad que ambos satíricos mantuvieron con los líderes políticos de su tiempo; y, en la selección que hace Trebacio de un tema luciliano (la laudatio), en el que Horacio podía imitar al inuentor sin problemas, aparece claro el reconocimiento de que la sátira tenía que adaptarse a las circunstancias políticas ${ }^{66}$.

A las invitaciones del jurista responde Horacio con una doble recusatio: para la épica le faltan fuerzas (vv.12-15) y para la laudatio no ha llegado aún el momento oportuno (vv.17-20). Además no puede dejar de escribir sátira porque, como a otros el vino o los caballos, lo que a él le gusta es escribir versos Lucili ritu; y evoca una faceta de la poesía de Lucilio que también podría cultivar sin herir a nadie ${ }^{67}$, la autobiográfica:

ille uelut fidis arcana sodalibus olim credebat libris neque, si male cesserat, usquam decurrens alio neque, si bene, quo fit ut omnis uotiua pateat ueluti descripta tabella uita senis. sequor hunc... (2.1.31-34)

Así respondía positivamente a las advertencias de su interlocutor sin forzar sus propias opciones poéticas, puesto que ya había cultivado este aspecto de la obra de Lucilio en algunas sátiras del libro primero (1.5; 1.6 y 1.9). La mención de la autobiografía luciliana lo lleva a la suya propia: evoca su lugar de nacimiento (vv. 39-40). Pero, en su juego de ambivalencias cuidadosamente medidas, Horacio nos recuerda que su origen, entre lucano y apulo, imprime en él un carácter violento y con esto nos devuelve a la potencial violencia de la agresividad satírica, que siempre está presente, ya permanezca latente, ya aparezca aunque sea para ser negada (Muecke 1995, 207; Keane 2006, 45-46). En este caso la pluma del satírico, el stilus, que es equivalente a una espada, solo servirá como arma defensiva, la que Horacio empleará sin clemencia cuando se sienta atacado, de manera que su víctima quede señalada y esté en boca de todos:

${ }_{65}$ Este verso - cum sibi quisque timet, quamquam est intactus, et odit-nos lleva a 1.4.33: omnes hi metuunt uersus, odere poetas.

${ }^{66}$ Keane $(2006,80)$ señala que en 2.1 encontramos una historia dinámica del género, igual que es dinámico el diálogo programático.

67 Trebacio tarda mucho en invocar abiertamente las leyes anti-libelo (vv.80-83), pero ya le advierte contra los riesgos que entraña tristi laedere uersu (21): laedere es uno de los términos latinos para 'difamar', una iniuria penalizada por la ley (Muecke 1995, 209) 
at ille

qui me conmorit (melius non tangere, clamo)

flebit et insignis tota cantabitur urbe (44-46)

Si el satírico había expulsado de su sátira la publicidad y difamación pública de sus víctimas (1.4.71-78), ¿cómo es que las recupera en su última sátira programática? Lo hace sí, pero con una gran diferencia: solo la utilizará como arma de defensa, como el lobo utiliza los dientes y el toro el cuerno; sí, en caso de que lo provoquen, se convertirá en un duro yambógrafo ${ }^{68} \sin$ atender a las advertencias de Trebacio, sean cuales sean las consecuencias (vv.57-59), pues el ejemplo de Lucilio, cuya agresividad perdonaron siempre Escipión y Lelio, le permite esperar que, de forma semejante, nunca dejen de apoyarlo sus dos poderosos amigos: Mecenas y Octaviano. Para DuQuesnay (1984, 26-29) Horacio estaría indicando con este paralelismo que había elegido el modelo de Lucilio para reivindicarse a sí mismo como un nuevo Lucilio y a sus amigos Octavio y Mecenas como defensores de la libertas siguiendo el ejemplo de Escipión y Lelio. Nos parece excesiva esta reducción de los motivos de Horacio para seguir a Lucilio; pero la propuesta de DuQuesnay subraya que Horacio en 2.1 deja selladas las relaciones de los poetas más representativos de la sátira con la política en dos periodos históricos diferentes: Lucilio en el periodo arcaico, él mismo en el clásico.

A esta diferencia parece responder el mantenimiento de las diferencias trazadas anteriormente en su programa, a pesar de que la imagen de Lucilio presentada aquí es más matizada y a pesar de la proximidad que establece con él en lo referente a su relación con los líderes políticos. De manera que seguimos encontrando la descripción de Lucilio como satírico duro:

'quid, cum est Lucilius ausus

primus in hunc operis componere carmina morem detrahere et pellem, nitidus qua quisque per ora cederet, introrsum turpis.............. (62-65)

La imagen para representar la agresividad de su acción satírica no puede ser más contundente: detrahere pellem, «arrancarle la piel a los hipócritas». Pero ahora por fin lo reconoce como primus, aunque de una manera bastante ambigua, pues por un lado parece que aquí tiene más peso el sentido cronológico del término que el de excelencia; por otro, si atendemos a la intertextualidad con la reclamación de primacía de Ennio, nos vemos obligados a matizar esa primera impresión:

\section{Cum neque Musarum scopulos nec dicti studiosus quisquam erat ante hunc. \\ Nos ausi reserare (7.1.215-217V)}

Ennio reclama para sí el perfeccionamiento artístico. La sutil presencia de su texto en el de Horacio nos lleva a recordar que Lucilio también había supuesto un

68 Cucchiarelli $(2001,116)$ nos recuerda que el poeta de 2.1 es también autor de yambos, que reflexiona sobre la legitimidad de sus censuras e invectivas. 2.1 es un poema en la encrucijada: el poeta aquí es equidistante de su doble personalidad poética. 
avance importante en el plano artístico con respecto a los poetas arcaicos, una virtud de su obra que ya reconocía Horacio en 1.10.64-71.

El cuidado con el que traza la imagen de Lucilio y su cercanía y distancia con respecto a ella se mantiene hasta el final; de manera que no nos sorprende que Horacio busque en el humor una salida a la amenaza de las leyes contra los mala carmina esgrimida por Trebacio - ius est iudiciumque, 83-: sus mala carmina, si por su estilo son bona según la autorizada opinión literaria del César, quedarán libres de castigo: soluentur risu tabulae, (v.86) el humor desactivará la demanda.

De esta forma se cierra una historia compuesta por Horacio con tanta habilidad para que se ajustara a sus intereses que con frecuencia ha sido tomada al pie de la letra por los críticos (Freudenburg 2001, 2), pero su sutileza, ironía, ambigüedades y ambivalencias no pueden ocultar su verdadero objetivo ni pueden oscurecer las líneas principales de la misma, como esperamos haber puesto de manifiesto.

\section{Referencias bibliografías}

Bakhtin, M. M. (1984), Problems of Dostoievsky Poetics, trans. and ed. Caryl Emerson, Manchester, Manchester University Press.

Barchiesi, A. (2001), «Horace and iambos: the poet as literary historian», en A. Cavarzere, A. Aloni \& A. Barchiesi (eds.), Iambic Ideas. Essays on a Poetic Tradition from Archaic Greece to the Late Roman Empire, Lanham [etc.], Rowman \& Littlefield, 141-160.

Brink, C. O. (1963), Horace on Poetry. Prologomena to the literary epistles, Cambridge, Cambridge University Press

Brink, C. O. (1982), Horace on Poetry III: Epistles, book II. Cambridge, Cambridge University Press.

Citroni, M. (1993), «Gli interlocutori del sermo oraziano: gioco scenico e destinazione del testo», in R. Uglione (ed.) Atti del convegno nazionale di Studi su Orazio, Turín, Regione Piamonte, Assessorato alla cultura, 99-127.

—, (2001), «Affermazioni di priorità e coscienza di progresso artístico nei poeti latini» en L'histoire littéraire immanente dans la poésie latine, Entretiens Hardt, 47, Ginebra, Vandoeuvres, 267-314

—, (2003), «I proemi delle "Tusculanae" e la costruzione di un'immagine della tradizione letteraria romana», en idem (ed.), Memoria e identità. La cultura romana costruice la sua immagine, Florencia, Università degli Studi di Firenze, Dipartamento di Scienze dell' Antichità «Giorgio Pasquali», 149-184.

—, (2004), «I precetti paterni e le lezioni dei filosofi: Demea, il padre di Orazio ed altri padri e figli», $M D$ 53, 9-63.

Coffey, M. (1989²), Roman Satire, Bristol, Classical Press.

Cortés Tovar, R. (1994), «Horacio y la sátira: canon y ruptura», en R. Cortés Tovar y J. C. Fernández Corte (eds.), Bimilenario de Horacio, Salamanca, Ediciones Universidad de Salamanca, 91-111.

-, (2005), «Libertas en la sátira: de Horacio a Juvenal», en J. F. González Castro et al. (eds.), Actas del XI Congreso Español de Estudios Clásicos, vol. II, Madrid, Sociedad Española de Estudios Clásicos, 785-793.

—, (2007), «Libertad de expresión en Juvenal: scribendi quodcumque ...liberet/simplicitas (I 152.153)», en G. Hinojo Andrés y J. C. Fernández Corte (eds.), Munus quaesitum meritis, 
Salamanca, Ediciones Universidad de Salamanca, 183-191.

-, (2017), «La construcción de la tradición del epigrama latino en Marcial», en Conventus classicorum, vol. I, Madrid, Sociedad Española de Estudios Clásicos, 785-792.

Courtney, E. (2013), «The Two Books of Satires», en Hans-Christian Günther (ed.), Brill’s Companion to Horace, Leiden, Brill, 63-168.

Cucchiarelli, A. (2001), La satira el il poeta: Orazio tra Epodi e Sermones, Pisa, Giardini.

—, (2007), «Come si legge la satira romana? », en K. Freudenburg-A. Cuchiarelli-A. Barchiesi (eds.), Musa pedestre. Storia e interpretazione della satira in Roma antica, (trad. e readaptación del inglés del The Cambridge Companion to Roman Satire (Cambrige UP, 2005), Roma, 167-202.

Delignon, B. (2006), Les Satires d'Horace et la Comédie gréco-latine: une Poétique de l'ambiguïté, Lovaina-París-Dudley, Ma, Peeters.

Di Benedetto, A. (1966), «I Giambi di Callimacho e il loro influsso sugli Epodi e Satire di Orazio», RAAN 44, 23-69.

Dickie, M. W. (1981), «The Disavowal of Invidia in Roman Iamb and Satire» Papers of the Liverpool Latin Seminar, 3, 183-208.

Dufallo, B. (2000), «Satis/Satura; reconsidering the 'programmatic intent' of Horace's Satires $1.1 » C W$ 93, 579-90.

Duquesnay, I. M. Le M. (1984), «Horace and Maecenas. The Propaganda value of Sermones I», en T. Woodman - D. West (eds.), Poetry and Politics in the Age of Augustus, Cambridge, Cambridge University Press, 19-58.

Feeney, D. (2002), «Una cum scriptore meo: Poetry, Principate and the Traditions of Literary History in the Epistle to Augustus», en T. Woodman and D. Feeney (eds.), Traditions and contexts in the Poetry of Horace, Cambridge, Cambridge University Press, 172-182.

-, (2009), «Becoming an authority: Horace on his own reception», en L. B. T. Houghton-M. Wyke (eds.), Perceptions of Horace: a Roman Poet and His Readers, Cambridge, Cambridge University Press, 16-38.

Ferris-Hill, J. L. (2011), «A Stroll with Lucilius: Horace, Satires 1.9 reconsidered», AJPh $132,429-455$.

-, (2015), Roman Satire and the old comic tradition, New York, Cambridge University Press.

Fowler, A. (1982), Kinds of Literature. An Introduction to the Theory of Genres and Modes, Clarendon Press, Oxford.

Freudenburg, K. (1993), The Walking Muse. Horace on the Theory of Satire, Princeton, New Jersey, Princeton University Press.

-, (2001), Satires of Rome: Threatening Poses from Lucilius to Juvenal, Cambridge, Cambridge University Press.

-, (2005), «Introduction», en Idem (ed.), The Cambridge Companion to Roman Satire, Cambridge, Cambridge University Press, 1-25.

Goldberg, S. 2005, Constructing Literature in the Roman Republic: Poetry and its Reception, Cambridge, Cambridge University Press.

Gowers, E. (2012), Horace, Satires Book 1, Cambridge, Cambridge University Press.

Heldmann, K. (1987), «Die Wesensbestimmung der horazischen Satire durch die Komödie» $A \& A 33,122-39$.

Hendrickson, G. L. (1927), «Satura tota nostra est», Classical Philology 22, 46-60

Hinds, S. (1997), «Do-it-Yourself Literary Tradition: Statius, Martial and Others», MD 39, 187-207.

-, (1998), Allusion and Intertext. Dynamics of Appropriation in Roman Poetry, Cambridge, Cambridge University Press. 
Hooley, D. M. (2007), Roman satire, Malden, Blackwell.

Hubbard, T. K. (1981), «The Structure and Programmatic intent of Horace's First Satire», Latomus 40, 315-321.

Hunink, V. \& D. Van Den Broek, (2010), «Stans pede in uno (Horace S. 1.4.10) », Mnemosyne $63,272-275$.

Hunter, R. L. (1985), «Horace on Friendship and Free Spech», Hermes 113, 480-490.

-, (2009), Critical Moments in Classical Literature, Cambridge, Cambridge University Press.

Kaster, R. A. (1995), De grammaticis et rhetoribus/ C. Suetonius Tranquillus, ed. with a translation, introduction and a commentary, Oxford, Clarendon Press

Keane, C. (2006), Figuring genre in Roman Satire, Oxford, Oxford Univerity Press.

Kennedy, D. F. (1992), «Augustan' and 'Anti-Augustan': Reflections on Terms of Reference», en A. Powell (ed.), Roman poetry and Propaganda in the Age of Augustus, Londres, Bristol Classical Press, 26-58

Labate, M. (2009² [1996]), «Horatian Sermo and Genres of Literature», en K. Freudenburg (ed.), Horace: Satires and Epistles, Oxford, Madrid [etc.], Oxford University Press, 102120.

Lafleur, R. A. (1981), «Horace and the 'onomasti komodein': The Law of Satire» Aufstieg und Niedergang der römischen Welt, II.31.3, 1790-826.

Leach, E. W. (1971), «Horace's pater optimus and Terence's Demea: Autobiographical Fiction and Comedy in Sermo 1.4», AJPh 92, 616-632.

Mañas Núñez, M. (2006), Arte poética y otros textos de teoría y crítica literarias, Cáceres, Uex.

Muecke, F. (1995), «Law, Rhetoric and genre in Horace, Satires 2.1» en S. J. Harrison (ed.), Homage to Horace. A Bimillenary Celebration, Oxford, Oxford University Press, 203218.

—,. (2005), «Rome's first 'satirist': themes and genre in Ennius and Lucilius», en K. Freudenburg (ed.), The Cambridge Companion to Roman Satire, Cambridge, Cambridge University Press, 33-46

—, (2013), «The Invention of Satire: a Paradigmatic case?» en Th. D. Papangalis, S. J. Harrison y S. Fraugoulids (eds.), Generics interfaces in latin literature. Encounters, interactions and transformations, Berlín, de Gruyter, 283-293.

Nasta, M. (2003), «La construcción de Lucilio en Horacio, Serm. I 4: estrategias para un cambio de indentidad poética», REC 31, 97-122.

Rosen, R. M. (2007), Macking Mockery. The Poetics of Ancient Satire, Oxford, Oxford University Press.

- , (2012), «Satire in the Republic: From Lucilius to Horace» en Susanna Braund and Josiah Osgood (eds.), A Companion to Persius and Juvenal, Malden, Wiley-Balckwell, 19-40.

Rudd, N. (1966), The Satires of Horace, Cambridge, Cambridge University Press.

Ruffell, I. A. (2003), «Beyond Satire: Horace, popular invective and the segregation of literature», JRS 93, 35-65.

Schlegel, C. (2005), Satire and the threat of speech: Horace's satires, book 1. Madison, University of Wisconsin Press.

Schmidt, E. A. (2001), «Einleitung», en L’histoire littéraire immanente dans la poésie latine, Entretiens Hardt, 47, Ginebra, Vandoeuvres, IX-XVIII.

Scodel, R. (1987), «Horace, Lucilius, and Callimachean Polemic», HSCPh 91, 199-215.

Sommerstein, A. (2011), «Hinc omnis pendet? Old Comedy and Roman Satire», CW 105, 1, 25-38. 
Tarrant, R. (2007), «Horace and Roman Literary History» en S. Harrison (ed.), The Cambridge Companion to Horace, Cambridge, Cambridge University Press, 63-76.

Van Rooy, C. A. (1965), Studies in Classical Satire and Related Literary Theory, Leiden, Brill.

Voit, L. (1980), «Ein kleines Horazproblem. Horaz und sein Gegner in der Sat. 1.4», Gymnasium 87, 401-410.

Zetzel, J. E. G. (1980), «Horace's Liber Sermonum: The Structure of Ambiguity», Arethusa $13,59-77$.

—, 2002, «Dreaming about Quirinus. Horace's Satires and the development of Augustan Poetry», en T. Woodman and D. Feeney (eds.), Traditions and contexts in the Poetry of Horace, Cambridge, Cambridge University Press, 38-52. 